D. C. Engerman

\title{
Mission from Moscow: Soviet Advisers and the Second Indian Five-Year Plan
}

David C.Engerman

$\mathrm{PhD}$, Leitner

International Interdisciplinary

Professor, Yale

University (New

Haven, USA)
When Soviet leaders Nikita Khrushchev and Nikolai Bulganin began their tour of India in November 1955, Pravda celebrated the visit with breathless references to the "flourish[ing] friendship between the Indian and Soviet peoples." While such rhetoric was - and would become even more familiar, it marked a significant change from earlier coverage that castigated India as an imperialist lackey. Khrushchev, Bulganin, and their large retinue considered their trip to India (continuing on to Burma and Afghanistan) a "mission of friendship"; they met with scholars, cultural figures, and Communist leaders. They spoke at rallies with tens of thousands of enthusiastic listeners, and made the obligatory visit to the Taj Mahal'.

Khrushchev and Bulganin's trip became the opening sally in the epic battle between the Cold War superpowers. The era of "competitive coexistence" (the American term) or "the competition between two systems" (its Soviet counterpart) soon encompassed much of the Third World. What American observers called the Soviet "economic offensive" led to the expansion of American aid programs in light of Soviet efforts - and then Soviet efforts accelerated in response to American initiatives ${ }^{2}$.

Yet Khrushchev and Bulganin's South Asian sojourn in the winter of 1955 did not come out of nowhere; it was merely 
the grandest event in the steady turn of Soviet attentions towards what was then coming to be called the Third World. A few months earlier, in June 1955, Jawaharlal Nehru had undertaken a similarly publicized trip around the Soviet Union. And a few months prior to that, in February 1955, Soviet and Indian officials had signed an agreement for Soviet technical and economic assistance in building a massive metallurgical complex in the North Indian city of Bhilai.

But before any of these well-publicized visits or agreements came a set of lower-profile exchanges that had just as profound an effect - if not more - on Indo-Soviet relations and perhaps on the Soviet Union itself. These visits in 1954-1956 were intended to shape India's Second Five Year Plan, which stood at the intersection of Indian economic history and the international history of the Cold War. This article examines some of the early Soviet contacts with Indian planners to show the effects on economists and economic ideas in both countries.

One of the key figures seeking the expansion of Indo-Soviet scientific ties was Prasanta Chandra Mahalanobis, a Bengali physicist-turned-statistician. The founding director of the Indian Statistical Institute (ISI), Mahalanobis also held the less-thanexalted title of Honorary Statistical Advisor to the Indian Cabinet - but more to the point had the ear of Jawaharlal Nehru when it came to questions of economic policy in the mid-1950s. Mahalanobis fashioned himself an impresario, making frequent trips to Moscow to promote Indo-Soviet scientific and cultural relations - and not coincidentally, to promote his own role as organizer. Among the records of the Academy of Sciences of the Soviet Union are numerous files containing upwards of 300 pages of letters about Mahalanobis's numerous trips and even more numerous proposals ${ }^{3}$. Though he made his first trip to Moscow in the dark days of late Stalinism, he was captivated: on his first visit to the Soviet Union in 1951, he gushed to a friend that his trip "was of crucial importance because I got a vivid impression of planning"4. Mahalanobis was hardly the only Indian intellectual enthusiastic about planning in the middle decades of the twentieth century; Nehru, too, was enthralled with the possibility of a rationally planned economy. Nehru had led the Indian National Congress's National Planning Committee in the 1930s, and upon Indian independence, Nehru chaired a Planning Commission. By the time Mahalanobis was in Moscow, India was already well its first Five-Year Plan (1951-1956) and would soon begin formulating its second. It was for this purpose that Mahalanobis especially sought Soviet expertise ${ }^{5}$.

A delegation from the Soviet Academy of Sciences arrived in Delhi in January 1954 to meet with senior government officials (including at least three meetings with Nehru) as well as Mahalanobis and other scholars. This initial delegation, sent to attend the Indian Science Congress, sought from the start to expand future Indo-Soviet connections ${ }^{6}$. Within a week of their return to Moscow, Academy of Sciences administrators began to organize a trip of specialists to visit Delhi.

While there were many topics of interest to the Indian government, including natural resource exploration and expanded trade opportunities, Soviet scholars quickly latched onto the provision of economic expertise as a means of expanding Soviet ties to and influence in India. Mahalanobis told the visitors that he sought their assistance in promoting his vision of economic planning. There were two tendencies 
in India during the First Five-Year Plan, he reported: the Minister of Finance and other economic officials sought to plan in financial terms, primarily focused upon government resources and investments. But Mahalanobis himself had a different vision for planning, one he claimed to share with Nehru and his circle. They had in mind a plan that encompassed all aspects of the economy, not just government spending; it would include the bulk of the economy that was in the private sector. It would be more interested in how much was produced and consumed rather than how much it cost - "physical" as opposed to "financial" planning. This vision shared much with the Soviet planning system's Balance of the National Economy (balans narodnogo khoziaistva), and thus Mahalanobis wanted to take advantage of the Soviet Union's "vast experience with planning." Thus, he claimed, Nehru's circle had a great need for Soviet advisors in planning. As committed as he was to seeking Soviet help, though, Mahalanobis did not want to roil international waters. He proposed that the exchange avoid the appearance of an official governmental program, and instead be organized between scholarly institutions - his ISI working with the much larger Soviet Academy of Sciences. "No need," he told his Soviet interlocutors, to "excite (draznit') those unfriendly to India and the USSR" by presenting his efforts as official acts. Finally, he suggested that each delegation's costs be covered by the country that sent it; this would reduce the appearance of dependence - and would have the added benefit of protecting Indian foreign exchange reserves ${ }^{7}$.

For their part, Soviet scholars were optimistic that a visiting delegation could serve multiple purposes. They noted that Indian scholars were well-versed in Anglo-American scholarship, but had little exposure to Soviet work. An effective delegation represented a chance to establish a Soviet beachhead in Indian intellectual life. If followed by an effort to translate Soviet publications into English, and with exchange programs bringing Indian scholars and students to the USSR, a Soviet delegation could be the first step in building Soviet intellectual influence in India more generally ${ }^{8}$.

Soviet aims went beyond general intellectual influence, though, and included hopes that they could shape Indian policy. Closer Indo-Soviet scholarly ties, one apparatchik noted, would also facilitate the "Iong-term strengthening the authority of the USSR and its science" in India. The president of the Soviet Academy of Sciences, A. N. Nesmeianov, quickly nominated a three-person delegation to travel to India before the end of 1954. Heading the list was M. I. Rubinshtein, a senior member of the Academy's Institute of Economics ${ }^{9}$. Rubinshtein had been at the State Planning Committee, Gosplan, in the decade after the 1917 Revolution. After a variety of economic posts and wartime service, he joined his colleague Jenö Varga in arguing that capitalism had stabilized the 1930s and 1940s. Varga and Rubinshtein argued that the New Deal and other efforts to fight the Depression, combined with the economic mobilization for World War II, meant that the final crisis of capitalism would be much delayed. Given the Soviet claims on the imminence of capitalist collapse and proletarian revolution, this position came at a high professional cost for Varga, though ironically it would become standard Soviet fare by the mid-1950s ${ }^{10}$. Rubinshtein, an important economist of his era, lent the delegation a certain prestige. At the same time, his intellectual independence, visible in the Varga affair, indicated that the 
Academy of Sciences was perhaps open to a broader rethinking of the newly independent nations. For their part, Indian economists were especially interested in the experience of Gosplan in the 1920s - tellingly, before the Stalinization of the Soviet economy that began in the late $1920 \mathrm{~s}^{11}$.

Rubinshtein's delegation, in the end, would not have much chance to exercise intellectual independence: along with Nesmeianov's nomination of the delegates to India were "Directive instructions" (direktivnye ukazaniia) for the delegation. Rubinshtein's group should "familarize Indian scholars with the history of the creation of the Soviet planned economy" in order to help India build its own planning apparatus. It should, specifically, show how the Soviets used economic regulation of industry, agriculture, and trade to create the fully planned economy. In a paragraph that revealed the short-lived ties between the USSR and the People's Republic of China, the orders also asked the delegation to highlight the value of the Chinese planning experience to their Indian hosts; this was particularly true for agriculture, where the orders recommended the Chinese rural economy - including peasant cooperatives - as a model for India. Moving beyond agriculture, Rubinshtein's delegation was also ordered to promote expanded industry in the public sector ${ }^{12}$. While Soviet officials hoped that the delegation would deepen Soviet-Indian relations, both the tenor and the content of the delegation's charge suggests that the relationship would not be between equals. Soviet scholars had much to teach their Indian counterparts, but the lessons were drafted well before departure. The lessons came from Soviet ideology and not from Indian circumstances or Indian scholars.

Mahalanobis used his next trip to Moscow in July 1954 to work out the details for the Soviet delegation trip to come that autumn, and to press the case for expanded Soviet ties ${ }^{13}$. Both sides came away from the conversations with heightened enthusiasm for the possibility of using Soviet experience and expertise to shape Indian planning. The Soviet Minister of Culture G. F. Aleksandrov covered a wide range of topics in his conversation with Mahalanobis, all of which would expand Soviet-Indian relations through the exchange of artistic delegations, films, music, and publications ${ }^{14}$. While Soviet officials were eager to build intellectual bridges to India, they hesitated to get directly involved in economic advising. As one memorandum regarding that 1954 delegation put it with scare quotes to demonstrate uncertainly about whether India was in fact engaged in planning in the Soviet sense:

The task of our Soviet economists should be limited to consultations, communicating our experience. We should not take responsibility for the formulation of a perspective "plan" or become official advisors and experts working out this "plan"15.

Mahalanobis apparently ignored such reticence. He envisioned flows of economic expertise in the context of a larger effort to "strengthen the bonds of friendship" between the two nations ${ }^{16}$. Not coincidentally, these connections would expand Mahalanobis's own role as culture broker. The relatively warm welcome Mahalanobis received from Soviet officials may well have been related to their confusion about his status; they treated him as a government official - which Mahalanobis encouraged - and referred to his organization, erroneously, as the Central Statistical Institute ${ }^{17}$. 
Cultural relations aside, Mahalanobis remained especially interested in economic planning, and his summer 1954 trip to Moscow left him excited about the future. He saw the budding connection with Soviet scholars and officials as providing the chance to advance his own agenda and his own career in India. He told his friend and colleague Pitamber Pant that Soviet advice and aid would be instrumental to building a planned economy. He queried Rubinshtein and others about general approaches as well as specific policies. He was reassured by their insistence that Chinese-style agricultural cooperatives could be organized without compulsion ${ }^{18}$. He responded with similar enthusiasm (and credulity) to Soviet talk of physical planning, which he saw as "the heart of planning" 19 . He told Soviet economists that planning was one route to undertake nationalization of industry, which he strongly supported ${ }^{20}$. Mahalanobis also sought Soviet assistance in bringing electronic computers to his ISI. In a breathless letter to Pant, Mahalanobis said he sought not aid but technology and technique: "it is not money, not money, NOT MONEY I am worrying about," but "technical knowledge." Mahalanobis was, in his own words, "greatly stimulated and excited by the possibilities of planning on the lines indicated by Soviet experts" 21 .

The Soviet delegation ultimately included nine scholars, a secretary, and three translators. Rubinshtein and fellow economists D. D. Degtiar' and L. Iu. Pisarev were based at Mahalanobis's ISI in Calcutta, where they interacted with scholars from all over the world - including planners like the French Marxist Charles Bettelheim and the Polish economist/planner Oskar Lange as well as the American Marxist Richard Goodwin (then teaching at the University of Cambridge). The Soviets devoted themselves to explicating the experience of the Soviet planned economy to fellow scholars at ISI as well as to other leading Indian officials. They contributed to debates over the fundamentals of the Second Five-Year Plan, including the emphasis on heavy industry, the use of physical (and not financial) planning, the best means to increase employment, and the size of the public sector. By their own reports, Soviet scholars were very much in line with Mahalanobis's own views ${ }^{22}$.

But members of the Soviet delegation hardly limited their interactions to scholars in Calcutta; they also operated in the corridors of official power. They met with Minister of Finance C. D. Deshmukh, Planning Commission Secretary Tarlok Singh, and Nehru himself, who visited ISI on Christmas Day 1954. Nehru's holiday talk included a strong plug for physical planning, also endorsed by the Soviet delegation - and which soon came in for sharp criticism in the Indian press. A seemingly technical matter of units of accounting of the plan, then, became an important marker of aspirations and inspirations for the Second $\mathrm{FYP}^{23}$. Soviet visitors also met frequently with the Planning Commission in February 1955, a crucial period in formulating the Second FYP. Degtiar' cited the Soviet experience in his discussion, and also was among those advisors promoting physical planning as a means of insuring a bold plan: India "should not allow financial resources to impede economic development"24.

Indeed, India's Second Five-Year Plan, debated between 1954 and 1956 and covering the period 1956-1961, expressed Indian officials' ambitions without reference to India's economic constraints. Nehru, working with his de facto planner-inchief, Prasanta Chandra Mahalanobis, offered a plan that differed dramatically from 
the somewhat scattershot and unambitious first plan; Mahalanobis called the first plan an "anthology," but wanted the second plan to be a "drama" 25. The Second Plan aimed to increase national income dramatically - by $5 \%$ per year. It also called for unemployment to be "liquidated" - common Soviet terminology — within a decade. The key to this growth would be heavy industry, which would be "expanded with all possible speed" - and in the public sector. Thus the Plan called for tripling steel production in only five years. This new industrial capacity would free India of the need to import steel while at the same time providing the spur for a more general economic expansion. To promote this sector, public expenditures on heavy industry almost tripled from the first plan, to the detriment of project spending on social services and agriculture ${ }^{26}$. The elaborate Indian planning process, which built on a widespread (if not universal) consensus about India's industrial future, hardly deterred policy-makers in the Cold War camps from trying to sway it.

American officials, too, tried to shape the plan. The Republican administration of President Dwight D. Eisenhower, for instance, dispatched economist Milton Friedman to Delhi in autumn 1955, hoping to spread the gospel of markets, free trade, and foreign investment. Friedman went to India wanting to change economic policy there - even though he had a realistic (and, ultimately, accurate) assessment of the low chance he would have an impact. In his memoirs, Friedman recalled that the Eisenhower administration sent him to India to "counter the influence of the leftwing advice" that Mahalanobis was receiving from others ${ }^{27}$. In fact, Friedman's trip came about after the head of America's aid agency agreed with the sympathetic Indian Finance Minister about the need to bring a distinguished economist to India "to consult on planning"28.

Like the Soviet delegation had, Friedman wrote his economic prescriptions before diagnosing Indian symptoms. Visiting Washington in August 1955 for predeparture briefings, Friedman left State Department officials with the impression that he "believed that a country must follow either an entirely free enterprise course or one mostly if not entirely regimented." He asked others at State about some of India's leading economic policy-makers, doubting that they really believed in the private sector since they endorsed public investment; promoting one public sector industry, Friedman insisted, was tantamount to rejecting private enterprise tout court. Conversations in India did little to convince him of any merits of a mixed economy; he wrote to his official sponsors after the trip that he was "struck" by "the disparity... between what [the Indian] government thinks it is doing and the facts of economic life"29. In a conversation with Tarlok Singh, Friedman realized the futility of his effort to effect changes to the Second Plan; "Apparently," he recorded in his notes, "major policy issues have been decided" 30 . Friedman's observation was astute. By the time Friedman arrived in late 1955, the broad parameters of the Second Plan were already well established; ISI economists were working out the details of the Plan, not the ultimate structure.

That structure, furthermore, bore some resemblance to the Soviet vision. Hence it is little surprise that Soviet observers, from Khrushchev and Bulganin through scholars at the Academy of Sciences, praised India's Second Five-Year Plan. As the doyen of Soviet Indologists, R. A. Ul'ianovskii, put it, "the fact that India 
is borrowing from the planning experience of the socialist countries in its effort to escape from backwardness and to suppress its economic dependence on foreign capital by the country's industrialization is fact of enormous progressive significance" 31 . Soviet observers by and large concurred with Mahalanobis's logic that rapid industrialization could serve as a protection against the depredations of global monopoly capitalism ${ }^{32}$.

Yet all of this cheerleading - Soviet observers rooting for public sector industry and planning, American experts for agriculture, private sector and markets - ultimately had little effect. While the economic advice was widely solicited, at great expense and effort for many individuals and institutions, the net effect of the whole foreign advising enterprise was very close to zero. This meager result was in large part by design; the purpose of the whole advising enterprise was not to emulate other models but to learn specific techniques, from Western economists and EastBloc planners alike. As Mahalanobis put it, "I am completely convinced that, if we are serious, we shall be able to get the fullest technical information and help in planning from the USSR." And his travels convinced him, he told one friend and colleague, that "there is nothing ready-made in the West which we can acquire or transfer... [but] I also know that we can use some of the Western economists to our great advantage" 33 . Reaching across the Cold War divide, then, Mahalanobis sought the technical expertise necessary to formulate the full Second Plan.

Yet the foreign experts and Mahalanobis's own overseas travels served another purpose as well. They provided external validation for the efforts of the Planning Commission, validation that Mahalanobis could (and did) cite in seeking domestic political support for his aims. The steady stream of visiting experts gave him the standing to defend policies that he had sought in the first place. As he was the first to acknowledge, foreigners' expert advice on economic planning helped win domestic political battles over the size and shape of the Second Five-Year Plan. He compared the role of foreign experts to "airforce cover for the army": their advice did not necessarily change the direction of attack, but provided helpful firepower supporting what was already under way ${ }^{34}$. Elsewhere Mahalanobis noted that the "greatest benefit" of the visitors was that they reinforced his ideas: "through contacts with such eminent experts from many different countries we gained confidence in our way of thinking"35. For all the rhetoric - from Americans and Soviets - about guiding the "young Republic of India" by proffering economic advice, then, Indian leaders pursued their own economic vision unaffected by all of the economic advice they worked so hard to obtain.

Yet the interactions of Soviet and Indian economists affected scholars from both countries. The introduction of a core concept of the Soviet economics in the 1950s and 1960s owed much to the Soviet encounter with India, and indeed had radical implications about the nature of socialism around the world. That concept the "non-capitalist path" was (like most innovations in Soviet thought) attributed to Lenin. It would be mistaken, the Bolshevik leader told a Comintern gathering in 1920, to assume that "the backward nations must go through the capitalist path of development" ${ }^{36}$. Khrushchev opened the door for a revival of this concept in one of his less-famous (and shorter) speeches at the Twentieth Party Congress in February 
1956: "The forms of the transition to socialism," he told Party leaders, will become all the more variable" and may not "always be connected with Civil War" 37 . Just as Khrushchev's widely publicized "Secret Speech" at the Twentieth Party Congress marked a turning point in Soviet history, so too did Khrushchev's remarks on the non-capitalist path consolidate a new approach to the Third World. As Politburo member Anastas Mikoian told Nehru shortly after the end of the Twentieth Party Congress, Khrushchev "did not formulate a new foreign policy; what [he] did was to give a more precise character to the policy which had been developed" over the previous year ${ }^{38}$.

A few months later M.I.Rubinshtein bolstered Khrushchev's claim from the Twentieth Party Congress when he published a two-part article in the high-profile English journal New Times. He argued that the path to socialism need not - as orthodox Marxists had long argued - run through capitalism en route to Communism. India's experience, Rubinshtein indicated, suggested an alternative path, one that might not even entail violent revolution. He rehearsed the recent talk of socialism in India, including the recent Congress Party declaration that its ultimate aim was to create a "socialistic pattern of society." Yet he drew a distinction between this "socialistic pattern" and socialism full stop. The rapidly expanding public sector was not, as American officials feared, tantamount to the arrival of socialism; it was instead what Rubinshtein called (again quoting Lenin) "state capitalism." State capitalism was progressive, in the Soviet framework, because it contributed to industrialization (and therefore the rise of an industrial proletariat) and because it was a blow to global capitalism. While Rubinshtein based his argument on evidence from India, he saw the "non-capitalist path" as relevant to much of the Third World. Chastising "dogmatists" who were determined to "squeeze realities into their own artificial schemes," Rubinshtein celebrated the concept of the non-capitalist path as proof of the "multiplicity of forms of socialist development" 39 . These claims of multiple forms of development marked a dramatic departure from Stalinist orthodoxy, and they carried with it significant implications not just for the emergence of socialism in the Third World, but also the possibility of different forms of actually existing socialism in Eastern Europe.

While Rubinshtein's explication of the "non-capitalist path" may seem like a response to Khrushchev's speech a few months earlier, Rubinshtein's earlier writings point to an alternative genealogy of the concept. Between his return from Delhi in 1955 and before Khrushchev's speech at the 20 2 th Party Congress, Rubinshtein published a handful of primarily factual reports on Indian planning - in which he suggested alternative trajectories for Indian economics and politics. First came an overview of economic development in India, in which he enumerated the key goals of the second Indian Plan while also drawing distinctions between the Indians' "socialistic pattern of society" and true socialism. In his closing paragraphs, he celebrated the chance to study the Indian present for what it revealed about the past and the future:

As a geologist at a huge section (razrez) sees strata of different geological eras, so too the economist can see firsthand in modern India the elements and the remnants of various socioeconomic systems. The remnants of the distant past, the complex and often contradictory present, and the first germs of the future are interwoven in a bizarre combination. Sometimes these germs 
[of the future] are still weak. They often try to drown the weeds of the old and obsolete world. But these germs will win because you can not slow the wheel of history (koleso istorii) ${ }^{40}$.

Contemporary India, in other words, contained a mixture of different historical stages along the inevitable path towards socialism. It was not, therefore, easily categorized in the familiar terms of Soviet Marxism, but was a "bizarre combination" all its own. Yet he was not yet ready to name that historical stage. Rubinshtein's next reflection on India was similarly guarded, but at the same time suggested a new conception of Indian development. As most Soviet observers did, he celebrated the emphasis on heavy industry, but praised it in unusual terms. Heavy industry was important, Rubinshtein insisted, because it provided a mechanism for establishing economic independence and also for improving the living conditions of the "popular masses." The notion that capitalist industrialization could improve living conditions was unusual, given that Rubinshtein elsewhere dismissed Indian claims that they were building socialism ${ }^{41}$. By the time Rubinshtein published a pamphlet on India in 1956, he emphasized the significant differences between Soviet and Indian approaches to economic issues, and noted that it was not the task of the Soviet Union (or, for that matter, of the Communist Party of India) to remake India in its own image ${ }^{42}$. And shortly thereafter came the New Times articles, which used India as a jumping-off point to articulate fully the theory of a non-capitalist path to development. Rubinshtein's travel to and studies of India, then, accelerated the broader Soviet reconsideration of the non-capitalist path, and with it a core element of Soviet eschatology. There was still one ultimate destination for history - Communism - but there was, theoretically at least, more than one way to get there. The Soviet encounter with India, its first close-up encounter with colonies and former colonies of Europe after the Stalinist deep-freeze, contributed to a major revision of Soviet ideology.

Ironically, then, the early missions from Moscow to Delhi had, perhaps, a stronger effect on the sending country than the recipients. Mahalanobis's enthusiasm for importing planning helped him build a technical edifice for his vision of Indian economic policy - and to build domestic support for it. But he did not seek to build an Indian version of Gosplan. For the Soviets, meanwhile, the encounter with India contributed to a reimaging of the developing world. The teachers, in other words, had learned from their students.

1 'Pust' protsvetaet druzhba naradov SSSR i Indii!', Pravda, 18 November 1955; Missiia Druzhby: Prebyvanie N.A. Bulganina i N. S. Khrushcheva v Indii, Birme, Afganistane, Ed. by P.A. Satiukov (Moscow, 1956).

2 On US initiatives, see: Kaufman B.I. Trade and Aid: Eisenhower's Foreign Economic Policy, 1953-1961 (Baltimore, 1982). — On Soviets, see especially: Berliner J.S. Soviet Economic Aid: The New Aid and Trade Policy in the Third World (New York, 1958). - For examples of the competitive spirit in Soviet aid, see Anastas Mikoian's comments at the Politburo meeting of 16 November 1955, in: Prezidium TsK KPSS 1954-1964, 3 vols, ed. by A.A. Fursenko (Moscow, 2003), vol.1, pp. 71-75; and "Nekotorye predlozheniia po razvitiiu ekonomicheskoi sviazei SSSR co slaborazvitymi stranami” (29 October 1958), RGANI 5/30/272/176-188.

3 Most of these documents are in the records of the International Department of the Academy of Sciences - ARAN fond 579. 
4 Mahalanobis to Pant, 24 June 1954, in Pitamber Pant Papers (Nehru Memorial Museum and Library/NMML).

5 V.P.D'iachenko to A. N. Nesmeianov, 3 July 1954, ARAN 579/03/504/58-59.

6 'Indiiskaia obshchestvennost' privetstvuet sotrudnichestvo Sovetskogo Soiuza i Indii', Izvestiia, 29 January 1954; 'Na sessii indiiskogo nauchnogo kongressa', Pravda, 6 January 1954; 'Ot”ezd delegatsii sovetskikh uchenykh iz Indii', Pravda, 1 February 1954.

7 G. F.Aleksandrov to K. V. Ostrovitianov, 23 February 1954, RGANI 5/30/70/1-10, esp. 2-4.

8 Aleksandrov to K. V. Ostrovitianov, 23 February 1954, RGANI 5/30/70/1-10.

9 A. N. Nesmeianov to M.A. Suslov, 26 February 1954, RGANI 5/28/242/7-8.

10 On Rubinshtein and Varga, see: Pollock E. Stalin and the Soviet Science Wars (Princeton, 2006), p. 192; Mommen A. Stalin's Economist: The Economic Contributions of Jenö Varga (New York, 2011), chaps. 13-14.

11 Mahalanobis's colleague Pitamber Pant was especially interested in the 1920s, when Rubinshtein's planning work began — noted in V. O. D'iachenko, "Otchet o poezdke v Indiiu," 12 November 1955, ARAN 579/1 (1956)/81/40-41.

12 "Direktivnye ukazaniia sovetskim uchenym, vyezzhaiushchim v Indiiu dlia okazaniia pomoshchi indiiskomu statisticheskomu institutu" (February 1954), RGANI 5/28/242/9-10.

13 A. N. Nesmianov to Central Committee, 12 July 1954; and Mahalanobis to Nesmeianov, 5 July 1954 - both in RGANI 5/30/71/114-118.

14 G. F. Aleksandrov to P. N. Pospelov, 23 July 1954, RGANI 5/30/71/94-100.

15 V.P.D'iachenko to A. N. Nesemianov, 3 July 1954, ARAN 579/3/504/58-59.

16 Mahalanobis to Pant, 7 July 1954, Pant Papers/NMML.

17 See, for instance, I. Kovalenko to S. G. Korneev, 29 May 1962, ARAN 579/1/1158/139.

18 Mahalanobis to Pant, 17 July 1954, Pant Papers/NMML.

19 Mahalanobis to Pant, 7 July 1954, Pant Papers/NMML.

20 E. N. Komarov, Report on Conversation with P.Ch. Mahalanobis, 12 July 1954, ARAN $579 / 3 / 535 / 8-13$.

21 Mahalanobis to Pant, 17 July 1954, Pant Papers/NMML.

22 K. V. Ostrovitianov, "Scientific Principles of the Planning of the National Economy of the USSR,” ISI Studies Relating to Planning for National Development, no. 18 (22 January 1955), in Planning Commission/ISI, Folder 15. D. D. Degtiar' to Pospelov, 24 May 1955, RGANI 5/30/117/4-38.

23 D.D. Degtiar' to Pospelov 24 May 1955, RGANI 5/30/117/4-38. Nehru's notes on his ISI visit appeared, translated into Russian, in the Records of the Central Committee's International Department — RGANI 5/28/344/94-97.

24 Planning Commission Minutes, 3 February 1955, in Planning Commission Records/ISI, Folder 116.

25 Rudra A.Prasanta Chandra Mahalanobis: A Biography (Delhi, 1996), p. 432.

26 Mahalanobis P. C. 'Recommendation for the Formulation of the Second Five-Year Plan' in Mahalanobis P. C. Talks on Planning (New York, 1961), p. 22; Chakravarty S. Development Planning: The Indian Experience (Oxford, 1987), table 9. - For general economic and policy debates, see: Frankel F.R. India's Political Economy, 1947-1977: The Gradual Revolution (Princeton, 1978), chaps. 2-5; Hanson A. H. The Process of Planning: A Study of India's Five-Year Plans, 1950-1964 (Oxford, 1966).

27 Friedman M., Friedman R.D. Two Lucky People: Memoirs (Chicago, 1998), pp. 257-262.

28 Harold Stassen memorandum of conversation with C.D.Deshmukh, 2 March 1955, in Stassen's report on India Trip, 21 March 1955, Declassified Document Reference System (DDRS), CK3100389521.

29 Roseman to Hollister, 4 August 1955, in Records of the U.S. Foreign Assistance Agencies (U.S. National Archives, RG469), entry UD181, box 22. Memorandum of Conversation between Jeffrey J.Jones and Friedman, 23 August 1955, in State Department Decimal Files (SDDF, U.S. National Archives, RG59), 891.00/8-2355. Memorandum of Conversation between Friedman and George Allen, 23 August 1955, SDDF, 891.00A/8-2355. Friedman was joined in this latter conversation — as in his trip to India - by UCLA economist Neil H. Jacoby, who had recently stepped down from service on President Eisenhower's Council of Economic Advisors. 
30 Friedman, "Notes on Conferences — New Delhi, India, October-November 1955," Milton Friedman Papers (Hoover Institution Archives), 226:12.

${ }_{31}$ Ulyanovskii R.A. 'Indiia v bor'be za ekonomicheskuiu nezavisimost (voprosy goskapitalizma)', Nezavisimaia Indiia: 10 let nezavisimosti, 1947-1957: sb. statei, eds V.V.Balabusevich, A. M. Dyiakov (Moscow, 1958), pp. 75-76.

32 Kondratyiev V. 'Natsional'naia burzhuaziia i promyshlennoe razvitie sovrenmennoi Indii', Mirovaia ekonomika $i$ mezhdunarodnaia otnosheniia, 1959, no. 8, p. 72; Pavlov V.I. Imperializm $i$ ekonomicheskaia samostoiatel'nost' Indii (Moscow, 1962), pp. 15-16.

33 Mahalanobis to Pant, 16 July 1954, Pant Papers (NMML).

34 Quoted, alas without citation, in: Clarkson S. The Soviet Theory of Development: India and the Third World in Marxist-Leninist Scholarship (Toronto, 1978), p. 267. - This section builds on the sources and interpretations examined by Clarkson and by Robert Remnek. See: Remnek R. Soviet Scholars and Soviet Foreign Policy: A Case Study in Soviet Policy toward India (Durham, 1975), chaps. 3-4.

35 Mahalanobis P.C. 'Approach of Operational Research to Planning in India', Sankhyā 16:1/2 (December 1955), p. 7.

36 Lenin V. I. 'Doklad komissii po natsional'nomu i kolonial'nomu voprosam' (2 July 1920), in Lenin V.I. Polnoe sobranie sochinenii, $5^{\text {th }}$ ed., vol. 41 (Moscow, 1974), p. 246.

${ }^{37}$ XX siezd Kommunisticheskoi Partii Sovetskogo Soiuza: stenograficheskii otchet, 2 vols. (Moscow, 1956), vol.1, pp.39-40. — See also: Hough J.F. The Struggle for the Third World: Soviet Debates and American Options (Washington, 1986), pp. 117-118.

38 Memorandum of conversation between Mikoian and Nehru, 26 March 1956, in Subimal Dutt Papers (NMML), Subject File 19.

39 Rubinstein M. 'Non-Capitalist Path', New Times, 5 July 1956, 2 August 1956.

40 Rubinshtein M.I. 'Ob ekonomicheskom razvitii sovremenoi Indii', Voprosy ekonomiki, 1955, no. 10, pp. 124-125.

${ }^{41}$ Rubinshtein M.I. 'Vtoroi piatiletnii plan Respubliki Indii', Sovetskoe vostokovedenie, 1956, no. 4, pp. 43-44.

42 Rubinshtein M. I. Ekonomicheskoe razvitie Respubliki Indii (Moscow, 1956), pp. 26, 56.

\title{
FOR CITATION
}

Engerman D. C. 'Mission from Moscow: Soviet Advisers and the Second Indian Five-Year Plan', Modern History of Russia, vol. 9, no. 3, 2019, pp. 685-696.

https://doi.org/10.21638/11701/spbu24.2019.309

UDC 94(47).084.9

\begin{abstract}
The article examines some early Soviet contacts with Indian planners to show effects on economists and economic ideas in both countries. Using documents from Soviet and Indian archives, this article traces effects of Soviet advisors working with the Indian Planning Commission at the crucial moment of formulating India's Second Five-Year Plan (1956-61). It shows how Soviet economists, most notably M. I. Rubinshtein, were part of an official effort to shape the direction of Indian economic policy — but also how Indian planners like P. C. Mahalanobis were able to use foreign visitors for support. It also suggests ways that the advising relationships in India may have had more effect on Soviet views of the Third World than on Indian plans. Mahalanobis's enthusiasm for importing planning helped him build a technical edifice for his vision of Indian economic policy and to build domestic support for it. For the Soviets, meanwhile, the encounter with India contributed to a reimaging of the developing world. Rubinshtein's travel to and studies of India, then, accelerated the broader Soviet reconsideration of the non-capitalist path, and with it a core element of Soviet eschatology. There was still one ultimate destination for history - Communism - but there was, theoretically at least, more than one way to get there.
\end{abstract}

Keywords: third world, India, USSR, economic advisors, M. I. Rubinshtein, P. C. Mahalanobis, USSR.

Author: David C. Engerman - PhD, Leitner International Interdisciplinary Professor, Yale University (New Haven, USA); david.engerman@yale.edu

Yale University, CT 06250, New Haven, USA 


\section{References:}

XX Congress of the Communist Party of Soviet Union: verbatim record, 2 vols. (Moscow, 1956). (In Russian) Berliner J. S. Soviet Economic Aid: The New Aid and Trade Policy in the Third World (New York, 1958).

Chakravarty S. Development Planning: The Indian Experience (Oxford, 1987).

Clarkson S. The Soviet Theory of Development: India and the Third World in Marxist-Leninist Scholarship (Toronto, 1978).

Frankel F. R. India's Political Economy, 1947-1977: The Gradual Revolution (Princeton, 1978).

Friedman M., Friedman R. D. Two Lucky People: Memoirs (Chicago, 1998).

Hanson A. H. The Process of Planning: A Study of India's Five-Year Plans, 1950-1964 (Oxford, 1966).

Hough J. F. The Struggle for the Third World: Soviet Debates and American Options (Washington, 1986).

Kaufman B. I. Trade and Aid: Eisenhower's Foreign Economic Policy, 1953-1961 (Baltimore, 1982).

Kondratyiev V. 'National bourgeoisie and the industrial development of modern India', Mirovaia ekonomika i mezhdunarodnaia otnosheniia, 1959, no. 8. (In Russian)

Lenin V.I. 'Report of the commission on the issue of nationalities', Lenin V.I. Polnoe sobranie sochinenii, 5th ed., vol. 41 (Moscow, 1974). (In Russian)

Mahalanobis P. C. 'Approach of Operational Research to Planning in India', Sankhyā 16:1/2 (December 1955). Mahalanobis P. C. Talks on Planning (New York, 1961).

Mommen A. Stalin's Economist: The Economic Contributions of Jenö Varga (New York, 2011).

Pavlov V.I. Imperialism and economic independence of India (Moscow, 1962). (In Russian)

Pollock E. Stalin and the Soviet Science Wars (Princeton, 2006).

Presidium TSK KPSS 1954-1964, 3 vols, ed. by A. A. Fursenko (Moscow, 2003). (In Russian)

Remnek R. Soviet Scholars and Soviet Foreign Policy: A Case Study in Soviet Policy toward India (Durham, 1975).

Rubinshtein M. I. Economic development of the Republic of India (Moscow, 1956). (In Russian)

Rubinstein M. 'Non-Capitalist Path', New Times, 5 July 1956, 2 August 1956.

Rubinshtein M.I. 'About the economic development of modern India', Voprosy ekonomiki, 1955, no. 10. (In Russian)

Rubinshtein M.I. 'The second five year plane of the Republic of India', Sovetskoe vostokovedenie, 1956, no. 4. (In Russian)

Rudra A. Prasanta Chandra Mahalanobis: A Biography (Delhi, 1996).

Ulyanovskii R. A. 'India in the struggle for economic independence (issue of state capitalism)', Nezavisimaia Indiia: 10 let nezavisimosti, 1947-1957: sb. statei, eds V.V. Balabusevich, A. M. Dyiakov (Moscow, 1958). (In Russian)

Received: March 5, 2019

Accepted: May 16, 2019 